\title{
The role of technology in an omnichannel physical store \\ Omnichannel physical store
} Assessing the moderating effect of gender El rol de la tecnología en una tienda física omnicanal

\section{Evaluando el efecto moderador del género}

\author{
Ana Mosquera, Cristina Olarte-Pascual, Emma Juaneda Ayensa and \\ Yolanda Sierra Murillo \\ Universidad de La Rioja, Logroño, Spain
}

\begin{abstract}
Purpose - The new omnichannel strategy aims to offer a holistic shopping experience through the integration of online and offline channels. The introduction of technology in the physical store is an essential factor to this end. The purpose of this study is twofold: first, to analyze how the intention to use different interactive technologies in a clothing store affects purchase intention and second, to test the moderating effect of gender on this relationship.

Design/methodology/approach - An original model is developed and tested with 628 omnichannel customers. A multi-group analysis is performed to compare the results between two groups: men and women.

Findings - The results show that the incorporation of new technologies in the physical store positively affects purchase intention, but no significant differences were found between the two groups.

Originality/value - This study furthers the understanding of the importance of the new connected retail system and offers new insights for both the theoretical framework and businesses.
\end{abstract}

Keywords Purchase intention, Omnichannel retailing, Moderating effect, Interactive technology, Physical clothing store, Omnichannel customer

Paper type Research paper

(C) Ana Mosquera, Cristina Olarte-Pascual, Emma Juaneda Ayensa and Yolanda Sierra Murillo. Published in Spanish Journal of Marketing - ESIC. Published by Emerald Publishing Limited. This article is published under the Creative Commons Attribution (CC BY 4.0) licence. Anyone may reproduce, distribute, translate and create derivative works of this article (for both commercial and non-commercial purposes), subject to full attribution to the original publication and authors. The full terms of this licence may be seen at http://creativecommons.org/licences/by/4.0/legalcode

The authors thank the Chair in Commerce at the University of La Rioja (Spain) for the financial support and A.M. acknowledges the C.A.R for an FPI grant.

Moreover, a version of this work has been previously published as working paper No. DOCFRADIS_1704 of the Working Documents Collection of the Ramón Areces Foundation of Commercial Distribution (http:catedrafundacionarecesdc.uniovi.es).

This research was funded by the Spanish Ministry of Economy and Competitiveness (Research Project reference: ECO2014-59688-R, National Program for Research, Development and Innovation Aimed at the Challenges of Society, National Plan of Scientific and Technical Research and Innovation 2013-2016).
Received 26 May 2017 Revised 29 June 2017 2 October 2017

20 November 2017 Accepted 16 December 2017 


\section{Resumen}

Objetivo - La nueva estrategia omnicanal busca ofrecer una experiencia de compra holística a través de la integración de los canales físico y online. Para ello, la introducción de nuevas tecnologías en el establecimiento es un factor esencial. Este estudio tiene un doble objetivo: primero, analizar como la intención de usar diferentes tecnologías interactivas en una tienda de moda afecta a la intención de compra; y segundo, comprobar el efecto moderador del género en esta relación.

Diseño/metodología - Se ha desarrollado un modelo original que fue testado en 628 consumidores omnicanal. Asimismo, se desarrolló un análisis multigrupo para comparar los resultados en dos grupos: hombres y mujeres.

Resultados - Los resultados muestran que la incorporación de nuevas tecnologías en la tienda física afecta positivamente en la intención de compra, sin embargo, no se han encontrado diferencias significativas entre los dos grupos estudiados.

Originalidad/valor - Este estudio mejora la comprensión de la importancia del nuevo comercio conectado y ofrece nuevas perspectivas tanto a nivel teórico como para los negocios.

Palabras clave - Tecnología interactiva, comercio omnicanal, tienda física de ropa, consumidor omnicanal, intención de compra, efecto moderador

Tipo de artículo - Trabajo de investigación

\section{Introduction}

The omnichannel concept is perhaps one of the most important revolutions in business strategy of recent years, with both practical and theoretical implications (Bell et al., 2014; Brynjolfsson et al., 2013; Piotrowicz and Cuthbertson, 2014; Verhoef et al., 2015), and the fashion industry has been one of the first to implement it ( $\mathrm{PwC}, 2016)$. Business experts use the term omnichannel to describe a form of retailing that allows customers not only to shop across channels but also to interact with the brand anywhere and at any time, providing them with a unique, complete and seamless shopping experience that breaks down the barriers between virtual and physical stores (Beck and Rygl, 2015; Lazaris and Vrechopoulos, 2014; Levy et al., 2013; Melero et al., 2016; Rigby, 2011; Verhoef et al., 2015). Advances in information technology and communication have led to an increase in the number of retailing formats through which consumers can contact a company. In addition to traditional physical and online stores, new channels and touchpoints, such as mobile, social media, smart TV and smart watches, are changing consumer habits and shopping behavior, transforming the buying process (Juaneda-Ayensa et al., 2016; Melero et al., 2016; Piotrowicz and Cuthbertson, 2014; Verhoef et al., 2015).

This fact has made selling to consumers truly complex (Crittenden et al., 2010) due to consumers' simultaneous evaluation of all channels and the resulting need for retailers to integrate all channels seamlessly to prevent cross-channel free-riding behavior (Chiu et al., 2011; Heitz-Spahn, 2013; Neslin et al., 2006; Pantano and Viassone, 2015).

In this new scenario, although shopping in physical stores is still the most popular way to buy clothing, the weight of the online channel in the fashion industry is growing and the gap between physical and virtual stores is shrinking ( $\mathrm{PwC}, 2016)$. Retailers must adapt to consumers' demands, incorporating new omnichannel technologies and practices to offer the best real-life and virtual purchasing options. In other words, physical stores should use a mixed model, combining the immediacy and multi-sensorial experience of a brick-andmortar store with the access, interactivity and convenience of an online one (Alexander and Alvarado, 2017). This new demand has a disruptive impact on the retail sector, forcing companies to transform their business models and customer relationship management strategies. Over the past years, a wide variety of technological innovations have been implemented in retail, such us augmented reality, digital signals, quick response $(\mathrm{QR})$ codes, beacons, tablets and free Wi-Fi (Piotrowicz and Cuthbertson, 2014). 
The literature reflects great interest among practitioners and scholars in the implementation of new technologies in stores. Studies have looked at how new in-store technologies can improve the shopping experience (Demirkan and Spohrer, 2014; Pantano and Di Pietro, 2012; Pantano and Viassone, 2015; Papagiannidis et al., 2013; Poncin and Ben Mimoun, 2014; Shankar, 2014) by increasing information richness (Parise et al., 2016) and encouraging the perception of innovation among customers (Atkins and Hyun, 2016). They have also found a positive relationship between the number of touchpoints and purchase intention (Suh and Lee, 2005). However, while real examples of the integration of interactive technologies in physical stores are on the rise, there is still a gap in the scientific literature regarding the role of technology in the physical store in an omnichannel environment (Brynjolfsson et al., 2013; Cook, 2014; Papagiannidis et al., 2013; Verhoef et al., 2015; Weill and Woerner, 2015). Due to this lack of empirical studies, this paper sought to determine which omniretailing technologies and uses matter most to consumers, as well as how consumers' intention to use such technologies and practices affects their purchase intention in an omnichannel clothing retail environment. This study also analyzed the moderating effect of gender on the relationship between the intention to use the aforementioned technologies and purchase intention. In this regard, some researchers have looked at genderbased attitudinal differences between men and women in relation to the use of information and communications technologies (ICTs) and in online contexts (Floh and Treiblmaier, 2006; Mittal and Kamakura, 2001). However, we have found no empirical studies analyzing the moderating role of gender on the influence of purchase intention in an omnichannel environment.

To achieve these goals, this paper will proceed as follows: first, we review the literature on omnichannel technologies in physical stores and the role of gender in shopping behavior. Second, we develop a model to understand how the introduction of new in-store technology would affect purchase intention. Third, we describe and explain the methodology used in the empirical study. Fourth, we examine the results and implications of the findings and derive our conclusions. Fifth and finally, we address the limitations of the research and suggest future lines of inquiry.

\section{Literature review and hypotheses}

The best way to think about omnichannel is to think about the evolution of retailing. It has been a 20-year journey, and it was not that long ago that retail was synonymous with brickand-mortar (Harris, 2012). With the advancement of e-commerce, a new channel emerged, and there began to be talk of multichannel retailing (Verhoef et al., 2015). However, although the multichannel concept allowed consumers to interact with the company through multiple touchpoints, it involved a silo-like division between the physical and virtual stores that caused consumers to have bad experiences (Beck and Rygl, 2015). Omnichannel is the final step in this evolution and consists in offering a comprehensive experience that merges the offline and online worlds (Mosquera et al., 2017). If all channels are connected, customers can start their shopping journey in one channel and finish it in another, creating a seamless experience that increases convenience and engagement (Alexander and Alvarado, 2017; Eaglen, 2013). It is a new wrapper on a very old principle, namely, that retailers should establish a conversation with their customers and center their strategy on them and their shopping experience (Gupta, Lehmann, and Stuart, 2004; Hansen and Sia, 2015; Shah et al., 2006).

As a result of technological advances, a new multi-device consumer has emerged who uses several channels simultaneously (Lazaris and Vrechopoulos, 2014) and whose experience is characterized by connectivity, mobility and multiple touchpoints (Aubrey and Judge, 2012; Harris, 2012). Described as channel agnostic, these consumers do not care whether they buy in-store, online or via mobile as long as they get the product they want when they want it at the right price (Aubrey and Judge, 2012), because what they ultimately 
SJME

22,1

want is to have the same brand experience regardless of the channel used (Dholakia et al., 2005; Eaglen, 2013; Juaneda-Ayensa et al., 2016; Zhang et al., 2010).

\subsection{Role of in-store technology}

In an omnichannel environment, technology is key to creating an integrated experience between channels, making the shopping experience both engaging and memorable (Piotrowicz and Cuthbertson, 2014). Although e-commerce continues to grow, physical stores are still the first choice for buying new clothing, as they provide the instant gratification of buying the product and play a central role in the development of a successful customer relationship (Blázquez, 2014).

However, the physical store is not just a place where consumers can see, feel, touch and try the products but also a place to provide them with attractive personal experiences, regardless of the channel used (Avery et al., 2012; Medrano et al., 2016). Thus, technology is redefining the store experience and store layouts through "click-and-collect," "ordering instore," "delivering to home," "order online, return to store" and other combinations of online and traditional retail activities that make the shopping process easier (Bell et al., 2014).

Recently, interactive in-store technologies have been implemented with the aim of increasing consumers' satisfaction and enhancing their shopping experience. Some of the most well-known technologies are virtual fitting rooms (Choi and Cho, 2012), augmented reality (Poncin and Ben Mimoun, 2014), digital signals (Burke, 2009), tablets (Rigby et al., 2012), automatic checkouts (Zhu, Nakata, Sivakumar, and Grewal, 2013), beacons (Shankar, 2014) and retail apps (Pantano and Priporas, 2016). Poncin and Ben Mimoun (2014) demonstrated that the experiential aspects of new in-store digital technologies may attract more shoppers to points-of-sale, reducing the boundaries between classical in-store atmospherics and e-atmospherics and possibly increasing sales. Moreover, offering more services while enriching traditional ones has been shown to increase consumers' purchase intention (Pantano, 2016; Renko and Druzijanic, 2014). Similarly, Verhoef et al. (2009) identified the issue of how technology affects shopping experience as one of the great questions. More recently, Verhoef et al. (2015) called for research into the role of the physical store in an omnichannel environment.

In this paper, we will differentiate between in-store technology in general and the technology used specifically in fitting rooms. By in-store technology, we mean the different devices that facilitate the shopping process at various points in the store. These technologies might include self-service technologies, iPads or tablets and other digital devices that allow the customer to perform different actions, such as automatic checkout systems to avoid lines or technologies that make it easier for customers to locate garments and sizes quickly in the store or, if those are not available or the customer does not want to be saddled with bags, to order them easily via a tablet and have them delivered to his or her home.

In contrast, fitting-room technology refers to technologies used specifically in fitting rooms. Fitting rooms are a place where many people make their final purchasing decision (Beck and Crié, 2015). This type of technology will thus be treated separately here. Some of the most well-known fitting-room technologies are the smart mirror or "virtual garment fitting system," which allows the customer to try clothes on virtually via a 3D bodyscanning system (Pantano and Viassone, 2014), and tablets, which allow the customer to choose different outfits, sizes or colors without leaving the fitting room, thereby making the experience more pleasant and convenient.

In light of the literature showing that technology attracts more consumers to the store (Demirkan and Spohrer, 2014; Pantano and Viassone, 2015; Papagiannidis et al., 2013; 
Poncin and Ben Mimoun, 2014; Shankar, 2014), we propose the following hypotheses with a view to advancing knowledge of the role of technology in omnichannel stores.

H1. The intention to use in-store technology positively affects purchase intention in an omnichannel clothing store.

H2. The intention to use fitting-room technology positively affects purchase intention in an omnichannel clothing store.

Omnichannel physical store

\subsection{Role of customer's own devices}

In an omnichannel environment, not only do the retailer's technologies but also those personal devices that customers use in the store, such as their smartphones, smartwatches and other wearables, matter. Numerous studies have highlighted that mobile technology has become a key tool at different moments before and during the shopping journey (Pantano and Priporas, 2016; Zagel et al., 2017). The nature of mobile devices, their physical characteristics and their size allow customers to search and shop anywhere and at any time (Gao et al., 2015; Rodríguez-Torrico et al., 2017). Today's consumers prefer to consult with their phones rather than interact with a salesperson while shopping at the store (Rippé et al., 2017). Thus, customers usually use their own devices in stores to search for more information about a product by scanning $\mathrm{QR}$ codes, comparing products, checking product ratings and asking for advice (Shankar, 2014; Verhoef et al., 2015; Voropanova, 2015). In addition, the advance of social media allows customers to share their satisfaction or dissatisfaction with a brand in real time (Deloitte, 2015). In short, today's "hyperconnected" consumers are willing to move seamlessly between different channels, touchpoints and platforms, whether at home, at work or in the store, using whichever device they consider most convenient at any given time, thinking of them as a whole (Cook, 2014; Frazer and Stiehler, 2014; Piotrowicz and Cuthbertson, 2014; Van Bruggen et al., 2010).

This consumer behavior poses several challenges, such as the practices of webrooming and showrooming. These behaviors differ depending on the channel that customers use most intensively to search for information and assess alternatives and on which one they choose to purchase the product. Webrooming occurs when consumers research a product online but ultimately buy it in a physical store (Flavián et al., 2016; Wolny and Charoensuksai, 2014). In 2007, Verhoef et al. (2007) described this behavior as the main omnichannel behavior. However, the rise of the use of smartphones in stores has enabled showrooming, whereby consumers use their own devices in-store, e.g. to compare product attributes or find offers (Babin et al., 2016; Rapp et al., 2015). Recent studies suggest that customers are replacing traditional searches with smartphones searches (Bachrach et al., 2016). This new way of gathering information through smartphones is due to the fact that mobile apps increasingly include features to facilitate and enhance the customer journey. Indeed, previous research has shown that enhancing the quality of the information and operations to be performed via smartphone in the store is positively related to purchase intention (Suh and Lee, 2005).

In their study on how companies are leveraging digital technologies with the aim of transforming the customer experience, Parise et al. (2016) found that "72 per cent of consumers said that a relevant mobile offer delivered to their smartphone while shopping in a store would significantly influence their likelihood to make a purchase." Likewise, Kim and Hahn (2015) determined that consumer adoption of mobile technology increased future purchase intention, whereas Rippé et al. (2017) more specifically demonstrated that in-store mobile searches are positively related to in-store purchase intention. 
SJME

22,1

68

\subsection{The moderating role of gender}

Consumer characteristics are relevant to the likelihood of engaging in a given behavior (Ajzen and Fishbein, 1980; Zhang, 2005). Thus, we introduced personal characteristics such as socio-demographic variables as variables that can affect purchase intention. Previous studies have shown that shopping behavior, approval and the acceptance and implementation of new technologies are influenced by personal characteristics, such as age, gender or educational attainment (Baker et al., 2007; Brown et al., 2003; Hasan, 2010; Hernández et al., 2009; Venkatesh et al., 2012; Zhou et al., 2007)

Gender in particular is a factor that influences both the purchase experience (Kolsaker and Payne, 2002; Zhou et al., 2007) and internet usage (Jackson et al., 2008; Zhang, 2005).

The empirical evidence on the influence of gender on behavior is contradictory (San Martín and Jiménez, 2011). Nevertheless, we believe that studying the moderating effect of gender could be valuable because it is one of the most commonly used variables in marketing segmentation due to its accessibility and simplicity. In addition, gender is the most important variable pertaining to the online purchase of clothing (San Martín and Jiménez, 2011). Among other differences between men and women in a fashion retail context, women tend to gather more information prior to making a purchase than men, are more involved in fashion and tend to spend more per purchase (Pentecost and Andrews, 2010; Shephard et al., 2016; Walsh et al, 2017).

Although some studies have been conducted on the importance of gender in the online context, the empirical evidence regarding the moderating role of this variable on the relationship between the intention to use interactive technology and purchase intention in an omnichannel store remains scarce. This paper thus seeks to further explore the moderating effect of gender on this relationship. Given the scant literature on this moderating effect, it will be incorporated through the following research proposition:

P1. Gender plays a moderating role in the positive relationship between the exploratory variables affecting purchase intention.

To determine the impact of technology in a physical clothing store, we developed a model with three hypotheses and one proposition related to the effect of the intention to use omniretailing technologies and practices on purchase intention in an omnichannel store (Figure 1).

Figure 1.

Research proposal

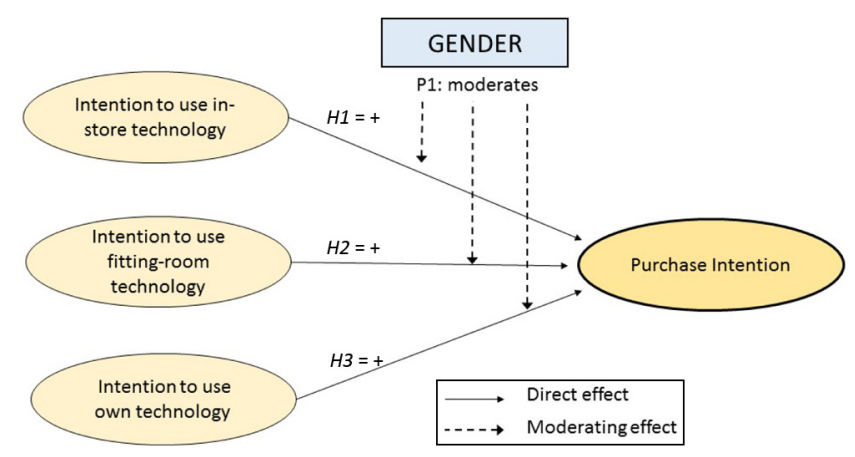




\section{Research method}

\subsection{Industry selection}

This research focuses on the clothing industry. This industry was chosen not only because of

the high revenues and number of jobs it generates but also because of its ability, as one of the fastest growing sectors in digital purchases, to attract different customer profiles through online and offline channels ( $\mathrm{PwC}, 2016)$. Moreover, apparel is one of the top ten categories most influenced by the in-store use of digital devices (Deloitte, 2016). The company Zara was chosen because it is one of the largest and most well-known clothing retailers in Spain to implement an omnichannel strategy. It thus allows its customers to use different channels simultaneously (physical store, online store, social media and mobile app) during their purchase journey. Last but not least, Zara has also implemented omnichannel technologies and practices at its physical stores, such as interactive signals and the possibility of paying via smartphone. In its store in San Sebastian (Spain), Zara has equipped the fitting rooms with tablets to allow customers to look for other sizes or garments to complete their outfits, pay via automatic checkout or use the free Wi-Fi.

\subsection{Measurement}

The measurement scale was borrowed from prior marketing literature, and the items related to the intention to use omnichannel retailing technologies and practices were adapted from Burke (2002) and Lazaris et al. (2015). To measure purchase intention, we used the scale developed by Pantano and Viassone (2015). We used purchase intention to describe the response in terms of intention to purchase in an omnichannel store (Table I). Participants were instructed to indicate their level of agreement with the items on a seven-point Likert scale ranging from 1 (totally disagree) to 7 (totally agree). Specifically, they were asked about their intention to use the various in-store omnichannel technologies and not their actual use of these technologies, as most of them, although popular online, have not yet achieved high penetration offline.

\subsection{Data collection}

Data were retrieved from an online survey focused on Spanish omnichannel clothing retail customers. For the purposes of our research, we defined omnichannel shoppers as those shoppers who use at least two channels of the same retailer during their shopping journey. The survey was conducted in January 2016. The sample consisted of 628 individuals who were representative of the distribution of online shoppers according to recent surveys (Corpora 360 and iab Spain, 2015) (Table II). Of the total number of surveys collected, 49.2 per cent of the respondents were male and 50.8 per cent female. By age, 51.1 per cent were 19-34 years old, 44.9 per cent were 35-54 years old and 4 per cent were 55 or older. With regard to educational attainment, 4.3 per cent had only a primary education, 33.7 per cent had a secondary education and 62 per cent had university studies. Finally, in terms of their omnichannel behavior, 81 per cent had used two channels in their last purchase process, 12 per cent had used three and 7 per cent had used four.

\subsection{Data analysis}

Partial least squares structural equation modeling was used to analyze the measurement model and test the hypotheses. The software used for this purpose was SmartPLS 3.0. The moderating effects of gender were analyzed by means of a multi-group comparison, as gender is a categorical variable (Henseler and Fassott, 2010). To this end, two groups were created: men and women. 


$\begin{array}{ll} & \text { In-store technology } \\ & \text { ST1 } \\ & \text { ST2 } \\ & \text { ST3 } \\ 70 & \text { ST4 } \\ & \text { ST5 }\end{array}$

Fitting-room technology FT1

FT2

FT3

FT4

Own technology

OT1

OT2

OT3

OT4

OT5

OT6

Purchase intention

PI1

PI2

PI3
I would use in-store technology to avoid lines

I would use in-store technology if I did not want to carry heavy bags

I would use in-store technology if the item/size were not available in the store

I would use in-store technology if I got discounts

I would use in-store technology if the online store had a larger assortment

I would use fitting-room technology to ask for advice without leaving the fitting room

I would use fitting-room technology to look for an item to complement my outfit I would use fitting-room technology to look for an item in another size or color

I would use fitting-room technology to share my look on social media

I would like the store to offer free in-store Wi-Fi

I would use my smartphone in-store to compare prices

I would use my smartphone in-store to look for opinions about a product

I would use my smartphone in-store to redeem discount coupons

I would use my smartphone in-store to pay

I would like Zara to send me information (e.g. about promotions/products) when I check in at the store

I would make a purchase in this kind of store

I would recommend making a purchase in this kind of store to a friend

I would like to repeat my experience in this kind of store

Table I.

Notes: ST (in-store technology); FT (fitting-room technology); OT (own technology); PI (purchase questionnaire intention)

\begin{tabular}{lcc}
\hline & Yes & No \\
\hline People with mobile data plans for their smartphone (\%) & 93.8 & 6.2 \\
In-store use of smartphone (\%) & 83.4 & 16.6 \\
Purchase frequency & & \\
Once a week & Physical store (\%) & Internet (\%) \\
Every two weeks & 7.6 & 6.2 \\
Every month & 19.9 & 9.9 \\
Every season & 29.1 & 21.0 \\
Once a year & 38.1 & 38.4 \\
Never & 5.1 & 15.8 \\
\end{tabular}

\section{Results}

\subsection{Validation and data analysis}

A regression analysis of the latent variables was performed, based on the optimization technique of partial least squares regression to develop a predictive model representing the relationships between the three proposed constructs and the purchase intention variable. 
To evaluate the measurement model, we examined and assessed item validity in terms of the standardized loadings (>0.70) and $t$-values (>1.96) (Hair et al., 2013). Based on the analysis of the items' contributions and relevance to the content validity of each factor, it was decided to remove the item "FT4" as the results showed it was not significant (Hair et al., 2013).

The measurement model was then verified in terms of construct reliability (i.e. composite reliability and Cronbach's alpha) and convergent validity (average variance extracted [AVE] (Table III shows the results). Discriminant validity was measured through the comparison of the square root of the AVE and the correlation among constructs (Roldán and SánchezFranco, 2012). The square root of the AVE must be greater than the corresponding interconstruct correlations; this criterion was met in all cases. In summary, the measurement instruments exhibited acceptable reliability and validity.

\subsection{Assessment of the structural model}

This section describes the effects on purchase intention of the use of technology in the store. The $R^{2}$ was 69.5 per cent for men and 62.9 per cent for women. Stone-Geisser's crossvalidity redundancy $\mathrm{Q}^{2}$ was 0.579 for men and 0.548 for women, confirming the predictive relevance of our model (Hair et al., 2011). Table IV also shows the AVE of each factor.

\begin{tabular}{lcccccr}
\hline Construct & CR $>0.7$ & Cronbach's $\alpha$ & AVE $>0.5$ & ST & FT & OT \\
\hline Men & & & & & & \\
ST & 0.924 & 0.897 & 0.709 & 0.842 & & \\
FT & 0.921 & 0.872 & 0.795 & 0.723 & 0.892 & \\
OT & 0.912 & 0.883 & 0.632 & 0.751 & 0.662 & 0.795 \\
PI & 0.941 & 0.906 & 0.842 & 0.784 & 0.682 & 0.764 \\
Women & & & & & & \\
ST & 0.903 & 0.866 & 0.652 & 0.808 & & \\
FT & 0.930 & 0.888 & 0.817 & 0.596 & 0.904 & \\
OT & 0.905 & 0.874 & 0.615 & 0.695 & 0.624 & 0.784 \\
PI & 0.956 & 0.931 & 0.879 & 0.688 & 0.699 & 0.682
\end{tabular}

Notes: CR (composite reliability); AVE (average variance extracted)

Omnichannel physical store
Table III.

Construct reliability, convergent validity and discriminant validity

\begin{tabular}{|c|c|c|c|c|c|c|c|c|}
\hline Relationship & $R^{2}(\%)$ & $\mathrm{Q}^{2}$ & $\begin{array}{l}\text { Direct } \\
\text { effects }\end{array}$ & Correlations & $\begin{array}{c}\text { Explained } \\
\text { variance } \\
(\%)\end{array}$ & $\begin{array}{c}p- \\
\text { Value }\end{array}$ & $\begin{array}{l}\text { Support for } \\
\text { hypotheses }\end{array}$ & \\
\hline \multicolumn{9}{|l|}{ Men } \\
\hline & 69.5 & 0.579 & & & & & & \\
\hline \multirow{3}{*}{\multicolumn{3}{|c|}{$\begin{array}{l}\text { H1: In-store tech. } \rightarrow(+) \text { Purchase intention } \\
\text { H2: Fitting-room tech. } \rightarrow(+) \text { Purchase intention } \\
\text { H3: Own tech. } \rightarrow(+) \text { Purchase intention }\end{array}$}} & 0.402 & 0.784 & 31.5 & 0.000 & Supported & \\
\hline & & & 0.152 & 0.682 & 10.4 & 0.005 & Supported & \\
\hline & & & 0.362 & 0.764 & 27.6 & 0.000 & Supported & \\
\hline \multicolumn{8}{|c|}{ Women } & Table IV. \\
\hline & 62.9 & 0.548 & & & & & & Effect of endogenous \\
\hline \multirow{3}{*}{\multicolumn{3}{|c|}{$\begin{array}{l}\text { H1: In-store tech. } \rightarrow(+) \text { Purchase intention } \\
\text { H2: Fitting-room tech. } \rightarrow(+) \text { Purchase intention } \\
\text { H3: Own tech. } \rightarrow(+) \text { Purchase intention }\end{array}$}} & 0.300 & 0.688 & 20.6 & 0.000 & Supported & variables, $t$-values \\
\hline & & & 0.368 & 0.699 & 25.7 & 0.000 & Supported & and support for the \\
\hline & & & 0.244 & 0.682 & 16.6 & 0.001 & Supported & hypotheses \\
\hline
\end{tabular}


SJME

22,1

Finally, the results show the significant influence of all the variables on purchase intention, supporting all hypotheses - H1 regarding the intention to use in-store technology, H2 regarding the intention to use fitting-room technology and $H 3$ regarding the intention to use the customer's own technology - for both men and women (Table IV).

The results showed that in-store technology was the strongest predictor of purchase intention in the case of men, followed by the concept of own technology, which refers to the technology that omnishoppers carry on their person (smartphones and other devices), and the technology offered in fitting rooms. In contrast, for women, fitting-room technology was the strongest predictor of purchase intention, followed by the intention to use in-store technology and own technology.

Specifically, as shown in Figure 2, the most important reasons for using in-store technology for men were to get discounts (ST4), to look for an item or size not available at the store (ST3) and to avoid carrying heavy bags (ST2). They were most likely to consider using fitting-room technology to look for other sizes and colors (FT3) and to look for clothes to complement their outfits (FT2). Finally, these omnishoppers used their smartphones in the physical store primarily to compare prices (OT2) and use discount coupons (OT4).

In contrast, as can be seen in Figure 3, women said they would use in-store technology to have a larger assortment (ST5), look for an item or size not available at the store (ST3) and get discounts (ST4). They were most likely to consider using fittingroom technology to ask for advice without leaving the fitting room (FT1) and to look for clothes to complement their outfits (FT2). Finally, they used their smartphones in the physical store primarily to compare prices (OT2) and search for opinions about the products (OT3).

Figure 2.

Measurement model for men

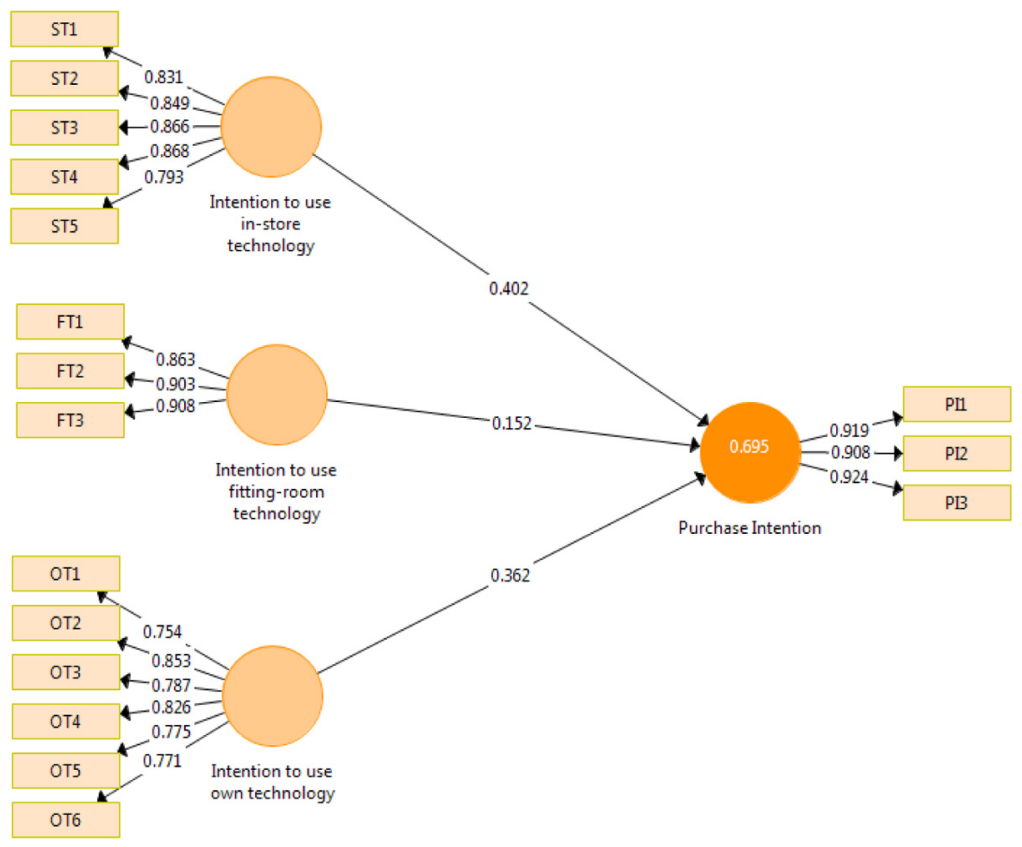




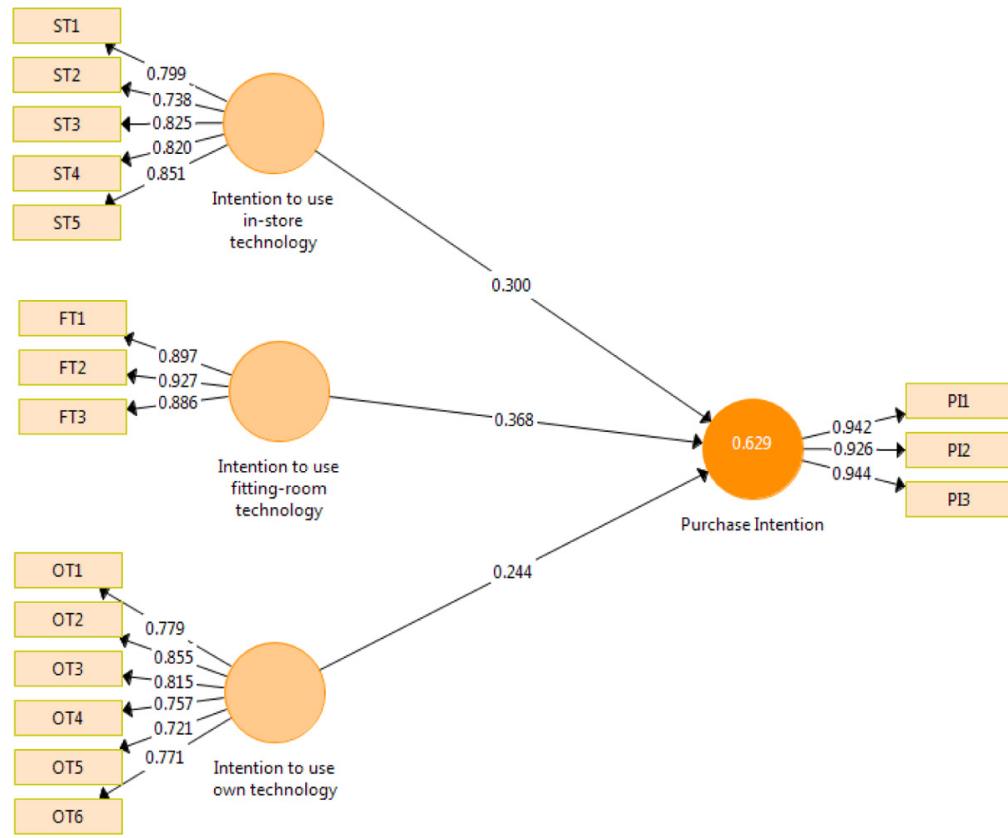

Omnichannel physical store

\subsection{Multi-group analysis}

A multi-group analysis was carried out to compare the results of the models for each group. We followed two approaches to determine the significance of the differences between the estimated parameters for each group. First, we conducted two parametric tests to analyze the differences between the models and to further assess possible moderating effects (Table V). Column $\mathrm{P}_{\mathrm{EV}}$ shows the $p$-values obtained applying the method proposed by Chin (2000). This method assumes that the data are normally distributed and/or the variances of the two samples are similar (Afonso et al., 2012). Column $\mathrm{P}_{\mathrm{W}-\mathrm{S}}$ shows the $p$-values obtained applying the Welch-Satterthwaite test in the cases where the variances of the two samples were different. The results of these two parametric tests were similar and did not reveal significant differences between the groups.

\begin{tabular}{lcccccc}
\hline & & & \multicolumn{4}{c}{ Confidence intervals } \\
Hypothesis & $\mathrm{P}_{\mathrm{EV}}$ & $\mathrm{P}_{\mathrm{W}-\mathrm{S}}$ & $\mathrm{P}_{\mathrm{H}}$ & $2.5-97.5 \%$ & $2.5-97.5 \%$ & Sig. \\
\hline Intention to use technology: men vs women & & & & & & \\
In-store tech. $\rightarrow$ Purchase intention & 0.266 & 0.265 & 0.133 & $0.277,0.506$ & $0.161,0.438$ & n.d. \\
Fitting-room tech. $\rightarrow$ Purchase intention & 0.025 & 0.025 & 0.988 & $0.050,0.283$ & $0.207,0.502$ & n.d. \\
Own tech. $\rightarrow$ Purchase intention & 0.211 & 0.210 & 0.104 & $0.240,0.475$ & $0.120,0.409$ & n.d.
\end{tabular}

Notes: Significance levels based on two-tailed Student's $t$-distribution (4.999). $\mathrm{P}_{\mathrm{EV}}=p$-value of the Henseler test; n.d. = no significant differences; $\mathrm{SD}=$ significant differences. When there is no overlap in the intervals in the confidence interval test, significant differences are considered to exist (Sarstedt et al., 2011)

Table V. Multi-group comparison 
Next, we applied non-parametric approaches exemplified by the Henseler test and the confidence interval test. Column $\mathrm{P}_{\mathrm{H}}$ shows the $p$-value obtained in the Henseler test. With regard to the confidence interval test, when the parameters estimated based on the confidence intervals for the two groups no overlap, a significant difference can be established between the two group-specific path coefficients (Pelegrín-Borondo et al., 2016). Based on this criterion, the non-parametric approaches did not reveal significant differences between the groups either. In light of the results of both types of tests (parametric and nonparametric), we decided to interpret the results with caution and to conclude that there were no significant differences at a confidence level of 95 per cent, as non-parametric tests are more restrictive (Sarstedt et al., 2011).

\section{Discussion and conclusions}

This work is an important contribution to the omnichannel literature as it shows what omnishoppers' favorite in-store technologies are and how the intention to use them affects purchase intention in an omnichannel retail environment. In today's increasingly competitive retail world, companies need to know which technologies and omnichannel practices are most attractive to their customers. An omnichannel store is one that blends the advantages of physical stores (e.g. the ability for consumers to see, feel, touch and try the product) with those of the online world (e.g. a greater product offering and 24/7 availability and information). The omnichannel strategy is centered on customers and their shopping experience and seeks to ensure seamless communication between the company and customer through the myriad channels and touchpoints throughout the shopping journey, allowing customers to interact with the brand through whatever channel they might choose at any given time.

The study aimed to explore consumers' intention to use technology in an omnichannel environment following the integration of different channels and technologies by a retailer in a physical store. More specifically, the study's aim was twofold: first, to explore how the intention to use in-store technology would affect purchase intention and determine which technologies and practices consumers consider most important in an omnichannel clothing store and second, to test the moderating effect of gender on this relationship.

The proposed model was found to sufficiently predict purchase intention in an omnichannel store for both groups, with an $R^{2}$ of 69.5 per cent for men and 62.9 per cent for women. Our findings support and provide further evidence for the idea that consumers' purchase intentions are influenced by their intention to use different digital technologies and practices in-store. However, we did not find statistically significant differences between the two groups - men and women - when applying the multi-group comparison to the three dimensions specified in the model. Thus, the moderating effect of gender was rejected in our study. This finding may be due to the fact that most of the sample population was collegeeducated (San Martín and Jiménez, 2011). Previous literature has confirmed that gender differences are smaller among college graduates, due to the deeper penetration and diffusion of ICT among people with a university education (Zhou et al., 2007).

This study suggests that consumers expect stores to offer them technological devices in the exhibition space, facilitate the use of their own devices and equip their fitting rooms with additional technological services. These findings are consistent with those of previous studies regarding the positive influence of incorporating interactive technologies on consumers' shopping behavior (Pantano and Servidio, 2012; Pantano and Viassone, 2015; Poncin and Ben Mimoun, 2014). Specifically: 
- In-store technology in men's clothing stores should provide information on item availability, supplement the information on the range of products and make it possible to avoid having to carry heavy bags. In addition, brands should facilitate the use of these customers' own mobile devices in their physical stores to obtain price-related advantages (e.g. to compare prices or obtain discount coupons).

- In-store technology in women's clothing stores should allow shoppers to browse a larger assortment of products and sizes. In addition, it should make it possible for staff to give them advice without the need for the shoppers to leave the fitting room and facilitate the use of their own smartphones to compare prices and search for opinions.

However, customers would not use the technologies provided by the brick-and-mortar stores to communicate on social media in either case. This may be because customers prefer to use their own devices to perform these types of social activities for privacy and security reason.

These findings have several important managerial implications for retailers. One key implication is that physical stores must adapt if they want to survive in the new environment. A brand's physical presence must add value in terms of service, product availability, engagement and the overall customer experience (Aubrey and Judge, 2012). As shown here, this could be achieved, for example, through the implementation of in-store technology (e.g. automatic checkout, tablets and free Wi-Fi) to allow customers to browse products and place orders. This is especially true of fitting-room technology, due to the importance of fitting rooms during the shopping process. Often, customers do not buy because they do not want to go to the fitting room and have to try things on, because they are alone and it is a nuisance to have to leave the fitting room to look for a garment in another size, etc. If retailers implement intelligent fitting rooms or install tablets to facilitate and expedite the purchase, many of these potential shoppers might decide to go to the fitting room and, ultimately, to make the purchase.

In addition, the store should facilitate the purchase process by allowing itself to be used as a collection point for online or mobile orders to make the store a place to build loyalty.

To offer a superior in-store experience, mobile app developers and retailers should focus not only on providing a supplemental shopping assistant interface but should also integrate this interface with hardware features that seamlessly blend the physical and online world (Lazaris, 2015). Companies must facilitate traffic between the online and physical store by making the same offers, conditions and services available on both channels (RodríguezTorrico et al., 2017). That way, customers will be able to compare prices, check stock availability in real time or interact with the brand, making the shopping process easier and more pleasurable and preventing free-riding consumer behaviors. Webroomers and showroomers can thus conduct their searches at the physical store and close the purchase on the spot, thanks to the technology implemented at the store. The webroomers will come to the store already informed about the product, to touch it before buying to make the decision with more confidence; showroomers will first make sure of the product they want to buy at the store, and then use their own smartphone or other technological devices available at the store to complete the shopping process after researching opinions, prices or product features.

In addition, retailers should invest in technologies that provide a seamless consumer experience across all available channels, to facilitate the shopping process and, thus, enhance customer engagement and loyalty to the brand (Cook, 2014; Pantano and Naccarato, 2010). Retailers must focus on the technology that is relevant for consumers and actually provides value (Blázquez, 2014); it must solve existing problems, not generate new ones. In this regard, the Internet of Things opens a world of possibilities for retailers, for 
example, by streamlining inventory management (connecting both the physical and virtual stores) and customer databases (making it possible to send personalized offers to each customer in real time) or by integrating technology into garments to improve their efficiency and make them more useful.

This paper also contributes to the literature on omnichannel retailing by identifying which technologies and omnichannel practices are most important for omnishoppers and how the intention to use in-store technology affects purchase intention. To our knowledge, it is the first academic, empirical study on the intention to use in-store technology in a clothing store in Spain that also analyzes the moderating effect of gender.

However, this study does have some limitations. First, the analysis is rather general, examining the use of interactive in-store technologies as a general concept. Another shortcoming of this paper is that it looks at consumer attitudes toward in-store technology without considering the cost of the technology, which might reduce retailers' willingness to adopt it. This cost can vary depending on the novelty of the technology, the level of realism it enables or the number of devices to be installed. In addition, our research did not take into account other important atmospheric factors, such as design, ambience or social factors, which also influence purchase intention. Moreover, our study was based on the specific case of an omnichannel clothing company that is only in the early stages of its strategy to implement interactive technology at its stores. A further limitation stems from the fact that the information is limited to Spain, which places constraints on any generalization of the model to other geographical and cultural spaces.

The findings reported here point to some interesting possibilities for future research, such as extending the study to other product categories or replicating it in another country to gather more generalizable consumer responses. Likewise, the moderating effect of other demographic and contextual variables, such as age, education level, product engagement or current in-store use by customers of their own devices, should be explored to complement the current model.

In sum, this study has sought to supplement previous studies on omnichannel retailing and the importance of technology in this new retail environment. Technology is changing the future of retailing. Retailers should thus offer deep omnichannel integration focused on the customer shopping experience, blurring the boundaries between offline and online channels and creating a holistic shopping experience, as customers want to interact with the brand, not the channels. The main technology challenge for brands will be to take advantage of the existing brand-customer interaction through mobile devices, as well as to understand customers' preferences to personalize the shopping experience using new marketing formats and technologies.

\section{References}

Afonso, C., Roldán, J.L., Sanchez-Franco, M. and Gonzalez, M. (2012), “The moderator role of gender in the unified theory of acceptance and use of technology (UTAUT) : a study on users of electronic document management systems", Proceedings of 7th International Conferenceon Partial Least Squares and Related Methods, Houston, TX.

Ajzen, I. and Fishbein, M. (1980), Understanding Attitudes and Predicting Social Behavior, Prentice Hall, EnglewoodCliffs NY.

Alexander, B. and Alvarado, D.O. (2017), "Convergence of physical and virtual retail spaces", Advanced Fashion Technology and Operations Management, IGI Global, pp. 191-219, available at: http://doi.org/10.4018/978-1-5225-1865-5.ch008 
Atkins, K.G. and Hyun, S.-Y.J. (2016), "Smart shoppers' purchasing experiences: functions of product type, gender, and generation", International Journal of Marketing Studies, Vol. 8 No. 2, pp. 1, available at: $\mathrm{http} / / / \mathrm{doi} .0 \mathrm{rg} / 10.5539 / \mathrm{ijms} . v 8 \mathrm{n} 2 \mathrm{p} 1$

Aubrey, C. and Judge, D. (2012), "Re-imagine retail: why store innovation is key to a brand's growth in the "new normal", digitally-connected and transparent world", Journal of Brand Strategy, Vol. 1 No. 1, pp. 31-39.

Avery, J., Steenburgh, T.J., Deighton, J. and Caravella, M. (2012), "Adding bricks to clicks: predicting the patterns of cross-channel elasticities over time", Journal of Marketing, Vol. 76 No. 3, pp. 96-111, available at: http://doi.org/10.1509/jm.09.0081

Babin, B.J., Borges, A. and James, K. (2016), "The role of retail price image in a multi-country context: France and the USA", Journal of Business Research, Vol. 69 No. 3, pp. 1074-1081, available at: http://doi.org/10.1016/j.jbusres.2015.08.023

Bachrach, D.G., Ogilvie, J., Rapp, A. and Calamusa, J. IV, (2016), "Price matching: to match or not to match?", More than a Showroom, Palgrave Macmillan, pp. 93-108.

Baker, E.W., Al-Gahtani, S.S. and Hubona, G.S. (2007), "The effects of gender and age on new technology implementation in a developing country: testing the theory of planned behavior (TPB)", Information Technology \& People, Vol. 20 No. 4, pp. 352-375, available at: http://doi.org/ $10.1108 / 09593840710839798$

Beck, M., Crié, D. (2015), "I virtually try it ... I want it ! virtual fitting room: a tool to increase on-line and off-line exploratory behavior, patronage and purchase intentions", Journal of Retailing and Consumer Services, Vol. 40, available at: http://doi.org/10.1016/j.jretconser.2016.08.006

Beck, N. and Rygl, D. (2015), "Categorization of multiple channel retailing in multi-, cross-, and omnichannel retailing for retailers and retailing", Journal of Retailing and Consumer Services, Vol. 27, pp. 170-178, available at: http://doi.org/10.1016/j.jretconser.2015.08.001

Bell, B.D.R., Gallino, S. and Moreno, A. (2014), "How to win in an omnichannel world", MIT Sloan Management Review, Vol. 56 No. 1, pp. 45-54.

Blázquez, M. (2014), "Fashion shopping in multichannel retail: the role of technology in enhancing the customer experience", International Journal of Electronic Commerce, Vol. 18 No. 4, pp. 97-116, available at: http://doi.org/10.2753/JEC1086-4415180404

Brown, M., Pope, N. and Voges, K. (2003), "Buying or browsing? An exploration of Shopping Orientations and Online Purchase Intention”, European Journal of Marketing, Vol. 37 Nos 11/12, pp. 1666-1684, available at: http://doi.org/10.1108/03090560310495401

Brynjolfsson, E., Hu, Y.J. and Rahman, M.S. (2013), "Competing in the age of omnichannel retailing”, MIT Sloan Management Review, Vol. 54 No. 4, pp. $23-29$.

Burke, R.R. (2002), "Technology and the customer interface: what consumers want in the physical and virtual store", Journal of the Academy of Marketing Science, Vol. 30 No. 4, pp. 411-432, available at: http://doi.org/10.1177/009207002236914

Burke, R.R. (2009), "Behavioral effects of digital signage", Journal of Advertising Research, Vol. 49 No. 2, pp. 180-185, available at: http://doi.org/10.2501/S0021849909090254

Chin, W.W. (2000), "Frequently asked questions - partial least squares \& PLS-graph", available at: http://disc-nt.cba.uh.edu/chin/plsfaq.htm

Chiu, H.C., Hsieh, Y.C., Roan, J., Tseng, K.J. and Hsieh, J.K. (2011), "The challenge for multichannel services: cross-channel free-riding behavior", Electronic Commerce Research and Applications, Vol. 10 No. 2, pp. 268-277, available at: http://doi.org/10.1016/j.elerap.2010.07.002

Choi, R. and Cho, C.S. (2012), "Introduction of a virtual fitting system for garment-online-retailing using front and back images of garment", International Conference on Hybrid Information Technology, Springer, Berlin, Heidelberg, pp. 309-316, available at: http://doi.org/10.1007/978-3-642-32692-9_40

Cook, G. (2014), "Customer experience in the omni-channel world and the challenges and opportunities this presents", Journal of Direct, Data and Digital Marketing Practice, Vol. 15 No. 4, pp. 262-266, available at: http://doi.org/10.1057/dddmp.2014.16 
SJME 22,1

Corpora 360 and iab Spain (2015), "Estrategia omnicanal del retail en España”, available at: http:// boletines.prisadigital.com/Estudio_Retail_Digital_2015.pdf

Crittenden, V.L., Peterson, R.A. and Albaum, G. (2010), “Technology and business-to-consumer selling: contemplating research and practice", Journal of Personal Selling and Sales Management, Vol. 30 No. 2, pp. 103-110, available at: http://doi.org/10.2753/PSS0885-3134300201

Deloitte (2015), "Omni-channel retail: a Deloitte point of view", available at: www2.deloitte.com/content/ dam/Deloitte/se/Documents/technology/Omni-channel-2015.pdf

Deloitte (2016), "Navigating the new digital divide", available at: www2.deloitte.com/in/en/pages/ strategy/articles/navigating-the-new-digital-divide.html

Demirkan, H. and Spohrer, J. (2014), "Developing a framework to improve virtual shopping in digital malls with intelligent self-service systems", Journal of Retailing and Consumer Services, Vol. 21 No. 5, pp. 860-868, available at: http://doi.org/10.1016/j.jretconser.2014.02.012

Dholakia, R.R., Zhao, M. and Dholakia, N. (2005), "Multichannel retailing: a case study of early experiences", Journal of Interactive Marketing, Vol. 19 No. 2, pp. 63-74.

Eaglen, M. (2013), "Omni-channel retail: joining up the consumer experience | media network | the guardian”, available at: www.theguardian.com/media-network/media-network-blog/2013/jul/22/ omni-channel-retail-consumer-experience (accessed 22 February 2017).

Flavián, C., Gurrea, R. and Orús, C. (2016), “Choice confidence in the webrooming purchase process: the impact of online positive reviews and the motivation to touch", Journal of Consumer Behaviour, Vol. 15 No. 5, pp. 459-476, available at: http://doi.org/10.1002/cb.1585

Floh, A. and Treiblmaier, H. (2006), "What keeps the e-banking customer loyal? A multigroup analysis of the moderating role of consumer characteristics on e-loyalty in the financial service industry", Journal of Electronic Commerce Research, Vol. 7 No. 2, pp. 97-110, available at: http://doi.org/ 10.2139/ssm.2585491

Frazer, M. and Stiehler, B.E. (2014), "Omnichannel retailing: the merging of the online and off-line environment”, Global Conference on Business and Finance Proceedings, Vol. 9 No. 1, pp. 655-657, available at: www.researchgate.net/profile/Cristobal_Fernandez/publication/260364142

Gao, L., Waechter, K.A. and Bai, X. (2015), "Understanding consumers' continuance intention towards mobile purchase: a theoretical framework and empirical study - a case of China", Computers in Human Behavior, Vol. 53, pp. 249-262, available at: http://doi.org/10.1016/j. chb.2015.07.014

Gupta, S., Lehmann, D.R. and Stuart, J.A. (2004), "Valuing customers", Journal of Marketing Research, Vol. 41 No. 1, pp. 7-18, available at: http://doi.org/10.1509/jmkr.41.1.7.25084

Hair, J.F., Ringle, C.M. and Sarstedt, M. (2011), "PLS-SEM: indeed a silver bullet”, Journal of Marketing Theory and Practice, Vol. 19 No. 2, pp. 139-152, available at: http://doi.org/10.2753/MTP10696679190202

Hair, J.F., Ringle, C.M. and Sarstedt, M. (2013), "Partial least squares structural equation modeling: rigorous applications, better results and higher acceptance”, Long Range Planning, Vol. 46 Nos 1/2, pp. 1-12, available at: http://doi.org/10.1016/j.lrp.2013.01.001

Hansen, R. and Sia, S.K. (2015), "Hummel's digital transformation toward omnichannel retailing: key lessons learned”, MIS Quarterly Executive, Vol. 14 No. 2, pp. 51-66, available at: http://search. ebscohost.com/login.aspx?direct=true\&db=buh\&AN=102933798\&site=ehost-live

Harris, E. (2012), "A look at omni-channel retailing”, available at: www.innovativeretailtechnologies. com/doc/a-look-at-omni-channel-retailing-0001 (accessed 22 February 2017).

Hasan, B. (2010), "Exploring gender differences in online shopping attitude", Computers in Human Behavior, Vol. 26 No. 4, pp. 597-601, available at: http://doi.org/10.1016/j.chb.2009.12.012

Heitz-Spahn, S. (2013), "Cross-channel free-riding consumer behavior in a multichannel environment: an investigation of shopping motives, sociodemographics and product categories", Journal of 
Retailing and Consumer Services, Vol. 20 No. 6, pp. 570-578, available at: http://doi.org/10.1016/j. jretconser.2013.07.006

Henseler, J. and Fassott, G. (2010), "Testing moderating effects in PLS path models : an illustration of available procedures", Hanbook of Partial Least Squares, Springer Berlin Heidelberg, pp. 713-735, available at: http://doi.org/10.1007/978-3-540-32827-8

Hernández, B., Jiménez, J. and Martín, M.J. (2009), “Age, gender and income: do they really moderate online shopping behaviour?”, Online Information Review, Vol. 35 No. 1, pp. 113-133, available at: http://doi.org/10.1108/14684521111113614

Jackson, L.A., Zhao, Y., Qiu, W., Kolenic Iii, A., Fitzgerald, H.E., Harold, R. and von Eye, A. (2008), "Culture, gender and information technology use: a comparison of Chinese and US children", Computers in Human Behavior, Vol. 24 No. 6, pp. 2817-2829, available at: http://doi.org/http://dx. doi.org/10.1016/j.chb.2008.04.007

Juaneda-Ayensa, E., Mosquera, A. and Sierra Murillo, Y. (2016), "Omnichannel customer behavior: Key drivers of technology acceptance and use and their effects on purchase intention", Frontiers in Psychology, Vol. 7, available at: http://doi.org/10.3389/fpsyg.2016.01117

Kim, J. and Hahn, K.H.Y. (2015), “The effects of self-monitoring tendency on young adult consumers' mobile dependency", Computers in Human Behavior, Vol. 50, pp. 169-176, available at: http://doi. org/10.1016/j.chb.2015.04.009

Kolsaker, A. and Payne, C. (2002), "Engendering trust in e-commerce: a study of gender-based concerns", Marketing Intelligence \& Planning, Vol. 20 No. 4, pp. 206-214, available at: http://doi. org/10.1108/02634500210431595

Lazaris, C. (2015), "Mobile apps for omnichannel retailing : revealing the emerging showrooming phenomenon", 9th Mediterranean Conference on Information Systems (MCIS), Samos, p. 12.

Lazaris, C. and Vrechopoulos, A. (2014), "From multichannel to "omnichannel" retailing: review of the literature and calls for research", 2nd International Conference on Contemporary Marketing Issues (ICCMI), Athens, available at: http://doi.org/10.13140/2.1.1802.4967

Lazaris, C., Vrechopoulos, A., Doukidis, G. and Fraidaki, K. (2015), "The interplay of omniretailing store atmosphere on consumers purchase intention towards the physical retail store", 12th European, Mediterranean \& Middle Eastern Conference on Information Systems (EMCIS), Athens, available at: http://doi.org/10.13140/RG.2.1.3928.3048

Levy, M., Weitz, B. and Grewal, D. (2013), Retailing Management, 9th ed., McGraw-Hill Education, New York, NY.

Medrano, N., Olarte-Pascual, C., Pelegrin-Borondo, J. and Sierra-Murillo, Y. (2016), "Consumer behavior in shopping streets: the importance of the salesperson's professional personal attention", Frontiers in Psychology, Vol. 7, available at: http://doi.org/10.3389/fpsyg.2016.00125

Melero, I., Sese, F. and Verhoef, P.C. (2016), "Recasting the customer experience in today's omni-channel environment”, Universia Business Review, Vol. 50, pp. 18-37, available at: http://doi.org/10.3232/ UBR.2016.V13.N2.01

Mittal, V. and Kamakura, W.A. (2001), "Satisfaction, repurchase intent, and repurchase behavior: investigating the moderating effect of customer characteristics", Journal of Marketing Research, Vol. 38 No. 1, pp. 131-142, available at: http://doi.org/10.1509/jmkr.38.1.131.18832

Mosquera, A., Olarte-Pascual, C. and Juaneda-Ayensa, E. (2017), "Understanding the customer experience in the age of omni-channel shopping", Revista Icono14 Revista Cientifica De Comunicación y Tecnologías Emergentes, Vol. 15 No. 2, pp. 166-185, available at: http://doi.org/ 10.7195/ri14.v15i2.1070

Neslin, S.A., Grewal, D., Leghorn, R., Shankar, V., Teerling, M.L., Thomas, J.S. and Verhoef, P.C. (2006), "Challenges and opportunities in multichannel customer management", Journal of Service Research, Vol. 9 No. 2, pp. 95-112, available at: http://doi.org/10.1177/1094670506293559

Omnichannel physical store 
SJME

22,1

Pantano, E. (2016), "Engaging consumer through the storefront: evidences from integrating interactive technologies", Journal of Retailing and Consumer Services, Vol. 28, pp. 149-154, available at: http://doi.org/10.1016/j.jretconser.2015.09.007

Pantano, E. and Di Pietro, L. (2012), "Understanding consumer's acceptance of technology-based innovations in retailing", Journal of Technology Management \& Innovation, Vol. 7 No. 4, pp. 1-19, available at: http://doi.org/10.4067/S0718-27242012000400001

Pantano, E. and Naccarato, G. (2010), "Entertainment in retailing: the influences of advanced technologies", Journal of Retailing and Consumer Services, Vol. 17 No. 3, pp. 200-204, available at: http://doi.org/10.1016/j.jretconser.2010.03.010

Pantano, E. and Priporas, C.V. (2016), "The effect of mobile retailing on consumers' purchasing experiences: a dynamic perspective", Computers in Human Behavior, Vol. 61, pp. 548-555, available at: $\mathrm{http}: / / \mathrm{doi} .0 \mathrm{rg} / 10.1016 / \mathrm{j} . \mathrm{chb} .2016 .03 .071$

Pantano, E. and Servidio, R. (2012), "Modeling innovative points of sales through virtual and immersive technologies", Journal of Retailing and Consumer Services, Vol. 19 No. 3, pp. 279-286, available at: http://doi.org/10.1016/j.jretconser.2012.02.002

Pantano, E. and Viassone, M. (2014), "Demand pull and technology push perspective in technology-based innovations for the points of sale: the retailers evaluation", Journal of Retailing and Consumer Services, Vol. 21 No. 1, pp. 43-47, available at: http://doi.org/ 10.1016/j.jretconser.2013.06.007

Pantano, E. and Viassone, M. (2015), "Engaging consumers on new integrated multichannel retail settings: challenges for retailers", Journal of Retailing and Consumer Services, Vol. 25, pp. 106-114, available at: http://doi.org/10.1016/j.jretconser.2015.04.003

Papagiannidis, S., Pantano, E., See-To, E.W.K. and Bourlakis, M. (2013), "Modelling the determinants of a simulated experience in a virtual retail store and users' product purchasing intentions", Journal of Marketing Management, Vol. 29 Nos 13/14, pp. 1462-1492, available at: http://doi.org/10.1080/ 0267257X.2013.821150

Parise, S., Guinan, P.J. and Kafka, R. (2016), "Solving the crisis of immediacy: how digital technology can transform the customer experience", Business Horizons, Vol. 59 No. 4, pp. 411-420, available at: http://doi.org/10.1016/j.bushor.2016.03.004

Pelegrín-borondo, J., Reinares-lara, E., Olarte-pascual, C. and Garcia-Sierra, M. (2016), “Assessing the moderating effect of the end user in consumer behavior: the acceptance of technological implants to increase innate human capacities", Frontiers in Psychology, Vol. 7, pp. 1-13, available at: http:// doi.org/10.3389/fpsyg.2016.00132

Pentecost, R. and Andrews, L. (2010), "Fashion retailing and the bottom line: the effects of generational cohorts, gender, fashion fanship, attitudes and impulse buying on fashion expenditure", Journal of Retailing and Consumer Services, Vol. 17 No. 1, pp. 43-52, available at: http://doi.org/10.1016/j. jretconser.2009.09.003

Piotrowicz, W. and Cuthbertson, R. (2014), "Introduction to the special issue information technology in retail: toward omnichannel retailing", International Journal of Electronic Commerce, Vol. 18 No. 4, pp. 5-16, available at: http://doi.org/10.2753/JEC1086-4415180400

Poncin, I. and Ben Mimoun, M.S. (2014), "The impact of e-atmospherics on physical stores”, Journal of Retailing and Consumer Services, Vol. 21 No. 5, pp. 851-859, available at: http://doi.org/10.1016/j. jretconser.2014.02.013

PwC (2016), Moda por un tubo? Informes PwC Retail y Consumo, available at: www.pwc.es/es/ publicaciones/retail-y-consumo/moda-por-un-tubo-relacion-cliente-omnicanal-sector-moda.html (accessed 17 March 2016).

Rapp, A., Baker, T.L., Bachrach, D.G., Ogilvie, J. and Beitelspacher, L.S. (2015), "Perceived customer showrooming behavior and the effect on retail salesperson self-efficacy and performance", Journal of Retailing, Vol. 91 No. 2, pp. 358-369, available at: http://doi.org/10.1016/j. jretai.2014.12.007 
Renko, S. and Druzijanic, M. (2014), "Perceived usefulness of innovative technology in retailing: consumers' and retailers' point of view", Journal of Retailing and Consumer Services, Vol. 21 No. 5, pp. 836-843, available at: http://doi.org/10.1016/j.jretconser.2014.02.015

Rigby, D. (2011), “The future of shopping”, Harvard Business Review, Vol. 89 No. 12, pp. 65-76.

Rigby, D., Miller, K., Chernoff, J. and Tager, S. (2012), "Omnichannel retailing: digital disruption and retailer opportunities", Bain Retail Holiday Newsletter, available at: http://goo.gl/47MwZX

Rippé, C.B., Weisfeld-Spolter, S., Yurova, Y., Dubinsky, A.J. and Hale, D. (2017), "Under the sway of a mobile device during an in-store shopping experience”, Psychology \& Marketing, Vol. 34 No. 7, pp. 733-752, available at: http://doi.org/10.1002/mar.21019

Rodríguez-Torrico, P., San José Cabezudo, R. and San-Martín, S. (2017), “Tell me what they are like and I will tell you where they buy. an analysis of omnichannel consumer behavior", Computers in Human Behavior, Vol. 68, pp. 465-471, available at: http://doi.org/10.1016/j.chb.2016.11.064

Roldán, J.L. and Sánchez-Franco, M.J. (2012), "Variance-based structural equation modeling: guidelines for using partial least squares in information systems research", Research Methodologies Innovations and Philosophies in Software Systems Engineering and Information Systems, pp. 193-221, available at: http://doi.org/10.4018/978-1-4666-0179-6.ch010

San Martín, S. and Jiménez, N.H. (2011), "Online buying perceptions in Spain: can gender make a difference? ”, Electronic Markets, Vol. 21 No. 4, pp. 267-281, available at: http://doi.org/10.1007/ s12525-011-0074-y

Sarstedt, M., Henseler, J. and Ringle, C.M. (2011), "Multigroup analysis in partial least squares (pls) path modeling: alternative methods and empirical results", Measurement and Research Methods in International Marketing, Vol. 22, pp. 195-218, available at: http://doi.org/10.1108/S1474-7979

Shah, D., Rust, R.T., Parasuraman, A., Staelin, R. and Day, G.S. (2006), "The path to customer centricity", Journal of Service Research, Vol. 9 No. 2, pp. 113-124, available at: http://doi.org/ 10.1177/1094670506294666

Shankar, V. (2014), Shopper Marketing and the Role of in-Store Marketing. In Shopper Marketing and the Role of in-Store Marketing, Emerald Publishing Limited, p. 3, available at: http://doi.org/ 10.1108/S1548-6435201411

Shephard, A., Pookulangara, S., Kinley, T.R. and Josiam, B.M. (2016), "Media influence, fashion, and shopping: a gender perspective", Journal of Fashion Marketing and Management, Vol. 20 No. 1, pp. 4-18, available at: http://doi.org/http://dx.doi.org/10.1108/09564230910978511

Suh, K.-S. and Lee, Y.E. (2005), "The effects of virtual reality on consumer learning: an empirical investigation”, MIS Quarterly, Vol. 29 No. 4, pp. 673-697, available at: http://doi.org/25148705

Van Bruggen, G.H., Antia, K.D., Jap, S.D., Reinartz, W.J. and Pallas, F. (2010), "Managing marketing channel multiplicity", Journal of Service Research, Vol. 13 No. 3, pp. 331-340, available at: http:// doi.org/10.1177/1094670510375601

Venkatesh, V., Thong, J.Y.L. and Xu, X. (2012), "Consumer acceptance and use of information technology: extending the unified theory of acceptance and use of technology", MIS Quarterly: Management Information Systems, Vol. 36 No. 1, pp. 157-178, available at: www.scopus.com/ inward/record.url?eid=2-s2.0-84859868870\&partnerID=tZOtx3y1

Verhoef, P.C., Kannan, P.K. and Inman, J.J. (2015), "From multi-channel retailing to omni-channel retailing: Introduction to the special issue on multi-channel retailing", Journal of Retailing, Vol. 91 No. 2, pp. 174-181, available at: http://doi.org/10.1016/j.jretai.2015.02.005

Verhoef, P.C., Lemon, K.N., Parasuraman, A., Roggeveen, A., Tsiros, M. and Schlesinger, L.A. (2009), "Customer experience creation: determinants, dynamics and management strategies", Journal of Retailing, Vol. 85 No. 1, pp. 31-41, available at: http://doi.org/10.1016/j.jretai.2008.11.001

Verhoef, P.C., Neslin, S.A. and Vroomen, B. (2007), "Multichannel customer management: Understanding the research-shopper phenomenon", International Journal of Research in Marketing, Vol. 24 No. 2, pp. 129-148, available at: http://doi.org/10.1016/j.ijresmar.2006.11.002 
SJME

22,1

Voropanova, E. (2015), "Conceptualizing smart shopping with a smartphone: implications of the use of mobile devices for shopping productivity and value", The International Review of Retail, Distribution and Consumer Research, Vol. 25 No. 5, pp. 529-550, available at: http://doi.org/ 10.1080/09593969.2015.1089304

Walsh, G., Schaarschmidt, M. and Ivens, S. (2017), "Effects of customer-based corporate reputation on perceived risk and relational outcomes: empirical evidence from gender moderation in fashion retailing", Journal of Product \& Brand Management, Vol. 26 No. 3, available at: http://doi.org/ 10.1108/JPBM-07-2016-1267

Weill, P. and Woerner, S.L. (2015), "Thriving in an increasingly digital ecosystem", MIT Sloan Management Review, Vol. 56 No. 4, pp. 27-34, available at: http://mitsmr.com/1BkdvAq

Wolny, J. and Charoensuksai, N. (2014), "Mapping customer journeys in multichannel decisionmaking”, Journal of Direct, Data and Digital Marketing Practice, Vol. 15 No. 4, pp. 317-326, available at: http://doi.org/10.1057/dddmp.2014.24

Zagel, C., Niels, A. and Bodendorf, F. (2017), "Using smartphones for information retrieval in omnichannel scenarios - assessing the effectiveness of technological triggers", Advances in The Human Side of Service Engineering, Springer International Publishing, pp. 151-159, available at: http://doi.org/10.1007/978-3-319-41947-3

Zhang, J., Farris, P.W., Irvin, J.W., Kushwaha, T., Steenburgh, T.J. and Weitz, B.A. (2010), "Crafting integrated multichannel retailing strategies", Journal of Interactive Marketing, Vol. 24 No. 2, pp. 168-180, available at: http://doi.org/10.1016/j.intmar.2010.02.002

Zhang, Y. (2005), "Age, gender, and internet attitudes among employees in the business world", Computers in Human Behavior, Vol. 21 No. 1, available at: http://doi.org/10.1016/j. chb.2004.02.006

Zhou, L., Dai, L. and Zhang, D. (2007), "Online shopping acceptance model: critical survey of consumer factors in online shopping", Journal of Electronic Commerce Research, Vol. 8 No. 1, 41-62, available at: http://doi.org/10.1086/209376.

Zhu, Z., Nakata, C., Sivakumar, K. and Grewal, D. (2013), "Fix it or leave it? Customer recovery from self-service technology failures”, Journal of Retailing, Vol. 89 No. 1, pp. 15-29, available at: http:// doi.org/10.1016/j.jretai.2012.10.004

\section{Corresponding author}

Ana Mosquera can be contacted at: ana-maria.mosquera@unirioja.es

For instructions on how to order reprints of this article, please visit our website:

www.emeraldgrouppublishing.com/licensing/reprints.htm

Or contact us for further details: permissions@emeraldinsight.com 